\title{
PENGEMBANGAN PEMBELAJARAN MANAJEMEN DATABASE BERBASIS WEB CMS JOOMLA PADA MAHASISWA PENDIDIKAN ADMINISTRASI PERKANTORAN FAKULTAS EKONOMI UNIVERSITAS NEGERI JAKARTA
}

\author{
RONI FASLAH \\ Fakultas Ekonomi Universitas Negeri Jakarta \\ ronifaslah@feunj.ac.id
}

\begin{abstract}
This study aims to research, develop, test, and validate learning media database management for students in courses of Economic Education Department of Economics and Administration Faculty of Economics, University of Jakarta. Second, this development aims to produce instructional media in the form of web-based learning with joomla cms. Third, determine the thoroughness of learning outcomes and student response to the learning process with the media joomla website.

This development method using silklus research and development ( $R$ \& $D$ Cycle) from Borg and Gall (1983) were modified. Based on the results of expert assessment, teachers and field trials on the product web-based learning media cms joomla, has obtained results that product development is considered feasible and has been able to facilitate the achievement of learning objectives. The results of field tests of the experimental class in this development means that the student assessment shows that the analysis of the media validator developed a valid entry in the category with a score of validity of 3.45. Criteria practicality of this medium can also be fulfilled for media media joomla website developed can be used with minimal revision. Student Learning Results showed that 31 students have a positive impact as indicated by the increased value of learning outcomes. The response of students to instructional media joomla website shows that as many as $96 \%$ of the students showed a positive response to learning this media joomla website.
\end{abstract}

Keywords: development, $R \& D$, database management, cms joomla

\section{PENDAHULUAN}

Perkembangan teknologi

informasi yang makin pesat pada era globalisasi saat ini secara berangsur-angsur mengubah beberapa aspek dalam kehidupan. Perubahan perkembangan teknologi mengubah bidang bisnis, ekonomi, 
pemerintahan dan juga pendidikan. Perubahan dalam bidang pendidikan mengubah sudut pandang mengenai sistem pembelajaran yang dulunya konvensional menjadi sistem pembelajaran modern. Pembelajaran yang berpusat pada guru sudah berubah menjadi pembelajaran yang berpusat pada peserta didik. Peserta didik juga dibebaskan dalam memperoleh sumber informasi atau bahan ajar tentang materi yang dipelajarinya. Bahan ajar dapat berupa bahan ajar cetak, audio, video, televisi, multimedia, dan web.

Bahan ajar merupakan informasi, alat dan teks yang diperlukan guru/ infrastruktur untuk perencanaan dan penelaahan implementasi pembelajaran. Bahan ajar adalah seperangkat materi yang disusun secara sistematis baik tertulis maupun tidak sehingga tercipta lingkungan/suasana yang memungkinkan siswa untuk belajar (Maryani, 2009). Menurut Tasri (2011), bahan ajar adalah segala bentuk content baik teks, audio, foto, video, animasi, dan lain-lain yang dapat digunakan untuk belajar.

Bahan ajar berbasis web adalah bahan ajar yang disiapkan, dijalankan, dan dimanfaatkan dengan media web (Tasri, 2011). Bahan ajar berbasis web sering juga disebut bahan ajar berbasis internet, bahan ajar on line atau $e$ learning.

Terdapat tiga karakteristik utama yang merupakan potensi besar bahan ajar berbasis web, yakni: menyajikan multimedia, menyimpan, mengolah, dan menyajikan informasi dan hyperlink. Beberapa kelebihan pembelajaran dengan menggunakan website antara lain fleksibel, independent learning, efisien, informasi real time, easy updating of content as well as archivable capabilities.

Bahan ajar berbasis web saat ini masih sangat minim, sehingga bagi peserta didik yang mencari bahan ajar di internet yang sesuai dengan standar isi dan kompetensi dasar akan merasa kesulitan. Lahir dan berkembangnya bahan ajar berbasis web dalam dunia pendidikan diharapkan mampu meningkatkan efektivitas dan efisiensi pendidikan. Pemanfaatan bahan ajar berbasis web sangat diperlukan dalam membangun sektor pendidikan di Indonesia, khususnya berkaitan dengan masalah akses pendidikan dan daya saing lulusan.

Hal ini sesuai dengan pendapat, Rohaety (2008:1) yang menyatakan bahwa menghadapi era globalisasi, dunia pendidikan indonesia harus berbenah diri dalam meningkatkan sistem informasi guna menunjang daya saing sumber daya manusia yang dihasilkan oleh lembaga pendidikan tersebut.

Di samping itu, dengan berkembangnya teknologi internet, pengelolahan data pun mulai banyak diarahkan dengan menggunakan sistem berbasis web. Data yang terkoneksi dengan 
jaringan baik jaringan lokal maupun jaringan internet akan mudah dijangkau oleh pengguna.

Perkuliahan

Manajemen

Database bagi mahasiswa Program

Studi Pendidikan Administrasi

Perkantoran Jurusan Ekonomi dan

Administrasi Fakultas Ekonomi

Unversitas Negeri Jakarta, selama ini hanya mengolah data-data lokal. Pada beberapa materi, mahasiswa juga diberi kemampuan untuk menangani dan mengolah data-data yang besifat online dan bagaimana cara memperoleh data tersebut.

Mahasiswa Program Studi Pendidikan Administrasi Perkantoran Jurusan Ekonomi dan Administrasi Fakultas Ekonomi Unversitas Negeri Jakarta tidak dirancang untuk memiliki kemampuan dalam merancang dan mendesain sebuah web karena mereka tidak memiliki basis sebagai programmer terlebih programmer web. Hal ini juga yang menjadi kendala ketika merancang dan mengolah data-data yang bersifat online.

Tetapi saat ini kondisi tersebut tidak lagi menjadi kendala, karena sudah banyak aplikasi yang dapat digunakan oleh mahasiswa sekalipun mereka tidak memahami perancangan dan desain sebuha web dan juga merancang dan mendesain aplikasi database berbasis web. Oleh karena itu perlu diberikan pengenalan dan pemahaman serta keterampilan secara konferehensif bahwa banyak aplikasi yang dapat digunakan untuk terampil membangun sebuah website tanpa harus mempelajari pemrograman web serta desain database online secara sederhana.

\section{Tujuan Penelitian}

Memperhatikan latar belakang di atas, penelitian ini bertujuan untuk memperoleh gambaran empirik tentang:

1. Mendeskripsikan proses pengembangan media website berbasis joomla.

2. Untuk mengetahui kevalidan hasil pengembangan media website berbasis joomla.

3. Untuk mengetahui ketuntasan hasil belajar siswa setelah mengikuti pembelajaran dengan media website berbasis joomla.

4. Untuk mengetahui respon siswa terhadap proses pembelajaran dengan media website berbasis joomla.

\section{TINJAUAN PUSTAKA \\ Mata Kuliah Manajemen Database}

Mata kuliah Manajemen Database bertujuan agar mahaiswa dapat membuat dan mengolah data dan informasi dalam bidang administras berbasis komputer. Mata kuliah ini meliputi perancangan database bukti transaksi, perancangan database kepegawaian, peracangan sistem kearsipan dan mengolah database. $D B M S$

(Database Management System) adalah sistem database tempat penyimpanan data yang datanya 
harus saling berhubungan dan memiliki relasi dengan yang lain, misalnya Oracle dan SQL Server. $D B M S$ adalah gudang data dari sistem. Kumpulan file yang tidak saling terkait satu sama lain tidak dapat disebut database (Oetomo, 2002:102). Untuk mengakses $D B M S$, digunakan bahasa SQL (Structured Query Language).

Sistem manajemen basis data (DBMS) adalah kumpulan data yang saling berhubungan dan kumpulan program untuk mengakses data.(Silberschatz, Janner Simarmata, 2006)

Database adalah sekumpulan file data yang satu sama lainnya saling berhubungan yang diorganisasi sedemikian rupa sehingga memudahkan untuk mendapatkan dan memproses data tersebut (Isak Rickyanto, 2004).

\section{Web Based Learning}

Website merupakan kumpulan dari halaman situs, yang terdapat dalam sebuah domain atau subdomain, yang tempatnya berada di dalam World Wide Web (www) di dalam Internet. Web merupakan kumpulan dokumen yang banyak tersebar di beberapa server yang berada di seluruh penjuru dunia dan terhubung menjadi satu jaringan melalui jaringan yang disebut internet.

Hampir $80 \%$ layanan internet adalah website. Faktor utama yang yang membuat website begitu cepat berkembang adalah karena penyebaran informasi melalui website sangat cepat dan mencakup area yang luas (mendunia), tidak dibatasi oleh jarak dan waktu.

Seiring dengan perkembangan teknologi informasi yang begitu cepat, website juga mengalami perkembangan yang sangat berarti (Mukhtar, 2012). Dalam pengelompokan jenis website lebih diarahkan pada fungsi, sifat dan bahasa pemograman yang digunakan.

Adapun website menurut sifatnya adalah:

a. Website dinamis merupakan website yang menyediakan content atau isi yang selalu berubah-ubah setiap saaat. Misalnya website berita, seperti detik.com, kompas.com, dan lain sebagainya.

b. Website statis, merupakan website yang kontennya sangat jarang diubah. Misalnya, website profil organisasi (Yuhefizar (2009).

Dalam pengembangan web based learning terdapat beberapa elemen yang perlu diperhatikan, seperti : interaktifitas (tutorial), pewarnaan, content, layout, dan lain-lain. Tutorial merupakan bagian dari proses pembelajaran. Tutorial merupakan satu bentuk interaksi antara pengajar (dosen/pakar) dengan mahasiswa. Interaksi dan komunikasi merupakan inti dari sebuah tutorial (Wardani, 2000).

Pembelajaran berbasis web merupakan suatu pembelajaran yang bisa diakses melalui jaringan internet. Pembelajaran berbasis web 
yang popular dengan sebutan webbased traning didefinisikan sebagai aplikasi teknologi web dalam dunia pembelajaran untuk sebuah proses pendidikan (Rusman, 2011). Secara sederhana dapat dikatakan bahwa semua pembelajaran yang memanfaatkan teknologi internet dan selama proses pembelajaran dirasakan terjadi oleh peserta didik atau siapa saja yang mengikutinya maka kegiatan itu dapat disebut sabagai pemeblajaran berbasis web.

Syarat utama yang harus dipenuhi melalui pembelajaran dengan web yaitu adanya akses dengan sumber informasi melalui internet dan juga tersedia sumber informasi tersebut yang bisa diakses oleh siapa saja dan kapan saja tanpa dibatasi ruang dan waktu.

Pembelajaran berbasis web itu unik tapi serius. Yang dimaksud serius disini adalah merancang sampai dengan mengimplementasikan pembelajarn berbasis web tidak semudah yang dibayangkan. Selain infrastruktur internet, Pembelajaran berbasis web memerlukan sebuah model instruktur yang memang dirancang khusus untuk keperluan pembelajaran. Model intruksional merupakan komponen vital yang menentukan keefektifan proses belajar. Adapun model intruksional yang dirancang, interaktivitas antara peserta didik, guru, pihak pendukung dan materi belajar harus mendapatkan perhatian khusus (Rusman, 2012).

\section{METODE PENELITIAN}

Penelitian ini merupakan penelitian pengembangan media pembelajaran dalam bentuk website manajemen database pada materi perancangan form. Metode penelitian pengembangan merupakan metode penelitian yang digunakan untuk menghasilkan produk dan menguji keefektifan produk tersebut. Untuk menghasilkan produk tertentu digunakan penelitian yang bersifat analisis kebutuhan dan untuk menguji keefektifan produk tersebut supaya dapat berfungsi di masyarakat luas, maka diperlukan penelitian untuk menguji keefektifan produk tersebut(Sugiono, 2010).

$$
\text { Subjek }
$$

penelitian pengembangan media internet melalui website berbasis joomla ini adalah mahasiswa Pen1didikan Administrasi Perkantoran Angkatan Tahun 2012 Program Studi Pendidikan Ekonomi Jurusan Ekonomi dan Administrasi Fakultas Ekonomi Universitas Negeri Jakarta.

$$
\text { Pengembangan media }
$$

website ini mengadopsi pada metode $R \& D$ yang ditulis oleh Sugiyono dalam bukunya yang berjudul Metode Penelitian Kuantitatif Kualitatif dan R\&D dengan adanya beberapa perubahan karena keterbatasan waktu menjadi seperti berikut: 


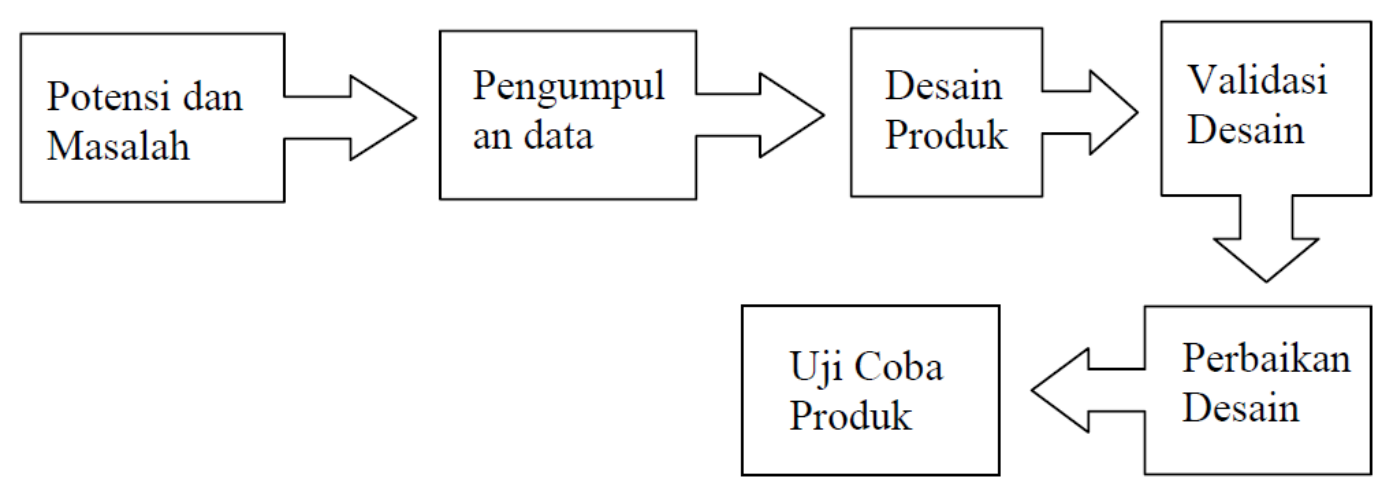

\section{Tahap Potensi dan Masalah}

Pembelajaran Manajemen

Database bertujuan diantaranya mahasiswa memiliki keterampilan dalam memperoleh dan mengolah data-data menjadi informasi yang bermanfaat. Salah satu kegiatan untuk mencapai tujuan tersebut, mahasiswa dibekali dengan keterampilan mendesain dan merancang pembuatan database dengan menggunakan software Microsoft Access. Misalnya untuk membuat sistem informasi kearsipan, sistem informasi kepegawaian, dll.

Perkembangan teknologi internet telah membawa perubahan terhadap sistem informasi berbasis online. Perkembangan ini juga telah menghasilkan produk-produk database yang dapat diakses melalui online. Banyak cara-cara memperoleh data dan keterangan dengan menggunakan online baru kemudian diolah menjadi informasi yang diperlukan. Misalnya pendaftaran online, mengambilan data mahasiswa online, dan lainnya.

Di satu sisi, mahasiswa Pendidikan Administrasi Perkantoran tidak didesain sebagai programer atau orang yang ahli dalam merancang dan membuat sebuah sitem. Maka diperlukan aplikasi yang mudah untuk digunakan.

Peneliti melihat ada peluang untuk mahasiswa dapat terampil merancang proses pengambilan data secara online dengan memanfaatkan CMS Joomla dan modul-modul pendukungnya. Dengan mengembangkan peluang ini, diharapkan dapat meningkatkan minat belajar mahasiswa dan meingkatkan keterampilan mahasiswa sehingga ketuntasan hasil belajar dapat dicapai oleh semua mahasiswa.

\section{Tahap Pengumpulan Data}

Pada tahap ini kegiatan yang dilakukan adalah mengumpulkan data-data yang dapat dijadikan sebagai sumber website joomla seperti yang terdapat dalam metode penelitian. Data-data yang dikumpulkan seperti modul pembelajaran manajemen database untuk dijadikan referensi materi dan kurikulum yang digunakan untuk menjabarkan standar kompetensi 
Roni Faslah: Pengembangan Pembelajaran Manajemen Database Berbasis Web CMS Joomla Pada Mahasiswa Pendidikan Administrasi Perkantoran FE UNJ

yang harus dicapai siswa, serta Elearning untuk dijadikan contoh pengembangan dalam website joomla ini dengan mengambil kelebihan dan membuang kekurangannya. Beberapa website lain yang isinya berkaitan serta mendukung dalam pengembangan website joomla ini dapat dijadikan sebagai link untuk menambah wawasan mahasiswa.

\section{Tahap Desain Produk}

Pada tahap ini yang dilakukan adalah desain media. Peneliti membuat website ini dengan menggunakan CMS Joomla yang di dalamnya memuat berbagai macam kompenen untuk mengatur website secara mudah. Dengan progam ini peneliti bisa membuat website sesuai dengan keinginan.

\section{Tahap Validasi Desain}

Website yang dihasilkan pada desain produk dikonsultasikan dan ditelaah oleh ahli untuk mendapat beberapa saran sekaligus divalidasi. Website divalidasi dan mendapat masukan kembali agar dihasilkan website yang valid dan layak digunakan untuk proses pembelajaran. Validator terdiri dari dosen manajemen database, ahli website, serta mahasiswa selaku obyek penelitian. Validator dimintai untuk menilai pada masingmasing aspek, serta memberikan saran pada lembar validasi yang disediakan.

\section{Tahap Perbaikan Desain}

Langkah selanjutnya adalah melakukan perbaikan desain oleh peneliti. Tahap ini dilakukan berdasarkan saran-saran perbaikan dari validator.

\section{Tahap Ujicoba produk}

Setelah dilakukan perbaikanperbaikan maka tahap selanjutnya adalah melakukan ujicoba desain pada mahasiswa. Peneliti yang berperan sebagai dosen menjelaskan bagaimana cara menggunakan website untuk pembelajaran. Mahasiswa diminta untuk mempelajari materi di website, mencoba mendesain sendiri latihan sesuai contoh yang terdapat pada website.

\section{HASIL DAN PEMBAHASAN}

Pada penelitian ini media pembelajaran yang dikembangkan adalah website yang dikembangkan menggunakan CMS joomla. Model pengembangan website ini mengadopsi pada model pengembangan Sugiyono yang terdiri dari potensi dan masalah, pengumpulan data, desain produk, validasi desain, revisi desain, dan uji coba produk.

Tahap-tahap yang dilakukan pada penelitian ini akan dijelaskan lebih lanjut sebagai berikut :

\section{Tahap Potensi dan Masalah}

Pembelajaran Manajemen

Database bertujuan diantaranya mahasiswa memiliki keterampilan dalam memperoleh dan mengolah 
data-data menjadi informasi yang bermanfaat. Salah satu kegiatan untuk mencapai tujuan tersebut, mahasiswa dibekali dengan keterampilan mendesain dan merancang pembuatan database dengan menggunakan software Microsoft Access. Misalnya untuk membuat sistem informasi kearsipan, sistem informasi kepegawaian, dll.

Perkembangan teknologi internet telah membawa perubahan terhadap sistem informasi berbasis online. Perkembangan ini juga telah menghasilkan produk-produk database yang dapat diakses melalui online. Banyak cara-cara memperoleh data dan keterangan dengan menggunakan online baru kemudian diolah menjadi informasi yang diperlukan. Misalnya pendaftaran online, mengambilan data mahasiswa online, dan lainnya.

Di satu sisi, mahasiswa Pendidikan Administrasi Perkantoran tidak didesain sebagai programer atau orang yang ahli dalam merancang dan membuat sebuah sitem. Maka diperlukan aplikasi yang mudah untuk digunakan.

Peneliti melihat ada peluang untuk mahasiswa dapat terampil merancang proses pengambilan data secara online dengan memanfaatkan CMS Joomla dan modul-modul pendukungnya. Dengan mengembangkan peluang ini, diharapkan dapat meningkatkan minat belajar mahasiswa dan meningkatkan keterampilan mahasiswa sehingga ketuntasan hasil belajar dapat dicapai oleh semua mahasiswa.

\section{Tahap Pengumpulan Data}

Pada tahap ini kegiatan yang dilakukan adalah mengumpulkan data-data yang dapat dijadikan sebagai sumber website joomla seperti yang terdapat dalam metode penelitian. Data-data yang dikumpulkan seperti modul pembelajaran manajemen database untuk dijadikan referensi materi dan kurikulum yang digunakan untuk menjabarkan standar kompetensi yang harus dicapai siswa, serta Elearning untuk dijadikan contoh pengembangan dalam website joomla ini dengan mengambil kelebihan dan membuang kekurangannya. Beberapa website lain yang isinya berkaitan serta mendukung dalam pengembangan website joomla ini dapat dijadikan sebagai link untuk menambah wawasan mahasiswa.

\section{Tahap Desain Produk}

Pada tahap ini yang dilakukan adalah mendesain sebuah website joomla yang nantinya akan digunakan sebagai media dalam pembelajaran. Website terdiri dari beberapa menu yang berisi contoh form aplikasi yang dapat menjaring data-data diantaranya: Pendaftaran Online, Pooling Online, Data Pengawai, dll. Prosesnya meliputi:

Dalam membuat website ini, Secara garis besar, Joomla terdiri dari 3 elemen dasar, yaitu server website (webserver), skrip PHP dan 
Roni Faslah: Pengembangan Pembelajaran Manajemen Database Berbasis Web CMS Joomla Pada Mahasiswa Pendidikan Administrasi Perkantoran FE UNJ

basisdata MySQL. Server web diasumsikan terhubung dengan internet atau intranet yang berfungsi sebagai penyedia layanan situs. Skrip PHP terdiri dari kode program dalam bahasa PHP dan basisdata yang merupakan tempat penyimpanan konten. Joomla menggunakan Apache sebagai server web dan MySQL untuk basisdatanya.

Pertama kali, pengguna meminta akses terhadap halaman joomla dengan mengeksekusi URL pada browser web yang kemudian terhubung dengan server web. Permintaan ini yang dalam istilah teknis lebih dikenal dengan query string selain terdapat URL juga mengandung parameter konten (section, category, ID article dan lainlain). Berdasarkan parameter tersebut, sistem skrip joomla melakukan kontak dengan basisdata dan mengambil konten yang dimaksud berdasarkan parameternya. Terakhir, konten dan templat (template) digabung bersama dan kembali sebagai halaman html, gambar, css dan javascript. Paket joomla terdiri dari beberapa bagian yang terpisah dan termodul yang sangat fleksibel, dapat dengan mudah dikembangkan dan diintegrasikan. Ada lebih tersedia 1,700 "plugins" yang secara resmi didelegasikan oleh Open Source Matters tersedia di http://extensions.joomla.org/ dan saat ini secara resmi dipindahkan ke http://joomlacode.org/ dengan dukungan server yang lebih lengkap. Aplikasi joom/a ini dapat di download di www.joomla.org

Setelah selesai mengunduh aplikasi maka unduh juga aplikasi webservernya yaitu xampp yang dapat di unduh di http://sourceforge.net/projects/xam pp. Masuk pada installasi website joomla localhost, langkah pertama yang dilakukan adalah menginstall aplikasi xampp yang berfungsi sebagai webserver dengan beberapa bagian di dalamnya. Kemudian copy aplikasi joomla yang sudah di unduh didalam menu Computer/Local Disk (C )/xampp/htdocs, dan extrak aplikasi joomla dengan nama folder "joomla". Hidupkan fungsi Aphace dan My SQL pada aplikasi xampp untuk menjalankan webserver local.

$$
\text { Selanjutnya dilakukan }
$$
instalasi joomla dan beberapa komponen pendukung yang dapat menunjang pembelajaran manajemen database, dalam hal ini mendesain form secara online.

\section{Tahap Validasi Desain}

Sebelum digunakan dalam kegiatan pembelajaran website ini harus mampu mempunyai status "valid". Idealnya seorang pengembang media perlu melalukan pemeriksaan ulang kepada para ahli (validator) mengenai ketepatan isi, materi pembelajaran, kesesuaian dengan tujuan pembelajaran, design fisik, dan lain-lain hingga dinilai baik oleh validator Proses validasi diharapkan dapat memberikan penilaian yang layak pada suatu 
website agar dapat digunakan untuk proses pembelajaran. Yakni dengan mendapatkan status valid atau sangat valid dari para ahli. Jika media pembelajaran berupa website belum valid, maka validasi akan terus dilakukan hingga didapatkan website yang valid.

Dalam penelitian ini, proses rangkaian validasi dilaksanakan selama 1 minggu, dengan validator yaitu mereka yang berkompeten dan mengerti tentang penyusunan media pembelajaran website dan mampu memberi masukan/saran untuk menyempurnakan media pembelajaran yang telah disusun. Saran-saran dari validator tersebut akan dijadikan bahan untuk merevisi website joomla ini.

Validator-validator tersebut memberikan penilaian untuk menentukan apakah media website ini valid untuk dijadikan media belajar . Kegiatan validasi website ini juga menghasilkan penilaian mengenai kepraktisan website. Penilaian kepraktisan ini bertujuan untuk mengetahui apakah website joomla ini layak digunakan untuk pembelajaran. Website dikatakan praktis jika validator menyatakan bahwa website ini layak digunakan tanpa revisi atau sedikit revisi.

\section{Revisi Desain}

Revisi desain ini berdasarkan saran-saran yang diberikan oleh validator pada saat validasi untuk menghasilkan website yang layak digunakan dalam proses pembelajaran. Validator menyarakankun untuk memperbanyak contoh form sehingga mahasiswa dapat belajar dari berbagai contoh dan mereka bisa menjadi lebih terampil dengan melakukan latihan melalui contohcontoh tersebut.

\section{B. Kevalidan Hasil Pengem- bangan Media Pembelajaran}

Dari validasi akan diketahui apakah website joomla yang sudah dibuat dapat dipakai dengan layak dalam ujicoba Terbatas. Media berupa website joomla yang dibuat peneliti divalidasi. Website joomla ini dinyatakan valid jika hasil penilaian dari validator $>3$. Hasil validasi website joomla oleh validator disajikan pada tabel 1 sebagai berikut: 
Tabel 1

Hasil Validasi Media Pembelajaran

1. Aspek Tampilan

\begin{tabular}{|c|l|c|c|}
\hline No & \multicolumn{1}{|c|}{ Komponen } & $\begin{array}{c}\text { Rerata Skor } \\
\text { Validator }\end{array}$ & \multirow{2}{*}{ Rerata per Aspek } \\
\hline 1 & Warna & 3,75 & \multirow{2}{*}{} \\
\cline { 1 - 2 } 2 & Tulisan & 3,5 & \multirow{2}{*}{3,5} \\
\hline 3 & Tata Bahasa & 3,0 & \\
\hline 4 & Tata Letak & 3,5 & \\
\hline 5 & Link & 3,75 & \\
\hline 6 & Kegunaan Gambar & 3,5 & \\
\hline
\end{tabular}

2. Aspek Materi

\begin{tabular}{|c|l|c|c|}
\hline No & \multicolumn{1}{|c|}{ Komponen } & $\begin{array}{c}\text { Rerata Skor } \\
\text { Validator }\end{array}$ & Rerata per Aspek \\
\hline 1 & $\begin{array}{l}\text { Memuat pengetahuan sesuai } \\
\text { unit kompetensi }\end{array}$ & 3,5 & \multirow{2}{*}{3,5} \\
\hline 2 & $\begin{array}{l}\text { Memuat keterampilan sesuai } \\
\text { unit kompetensi }\end{array}$ & 3,5 \\
\hline 3 & $\begin{array}{l}\text { Bahasa mudah dimengerti } \\
\text { Contoh dan latihan cukup } \\
\text { membantu mencapai } \\
\text { kompetensi }\end{array}$ & $\begin{array}{l}\text { Materi pelajaran sesuai dengan } \\
\text { tingkat peserta didik }\end{array}$ & 3,75 \\
\hline 6 & $\begin{array}{l}\text { Memungkinkan peserta didik } \\
\text { belajar secara mandiri }\end{array}$ & 3,25 & \multirow{2}{*}{3,4} \\
\hline 7 & $\begin{array}{l}\text { Tugas dan latihan sesuai } \\
\text { dengan kompetensi yang ingin } \\
\text { dicapai }\end{array}$ & 3,5 \\
\hline 8 & $\begin{array}{l}\text { Materi diorganisasikan secara } \\
\text { sistematis }\end{array}$ & 3,5 \\
\hline
\end{tabular}

Dari tabel tersebut diperoleh informasi bahwa website joomla yang dikembangkan dalam pembelajaran manajamen database termasuk dalam kateogri valid dengan nilai rata-rata total kevalidan sebesar 3,45.

\section{Kepraktisan Hasil Pengem- bangan Media Pembelajaran}

Pada Bab III telah dijelaskan bahwa suatu media dikatakan praktis jika para ahli (validator) menyatakan bahwa media berupa 
website joomla dapat digunakan tanpa revisi atau sedikit revisi. Berdasarkan hasil penilaian secara umum terhadap media berupa website joomla, diperoleh hasil sebagai berikut:

Tabel 2

Penilaian Validator Mengenai Aspek Kepraktisan

\begin{tabular}{|c|l|}
\hline Validator & \multicolumn{1}{|c|}{ Penilaian website joomla secara keseluruhan } \\
\hline 1 & Layak digunakan \\
\hline 2 & Layak digunakan dengan sedikit revisi \\
\hline 3 & Layak digunakan \\
\hline 4 & Layak digunakan dengan sedikit revisi \\
\hline
\end{tabular}

Dari keempat validator dapat disimpulkan bahwa website joomla ini memenuhi aspek praktis sehingga website ini layak digunakan.

\section{Penilaian Hasil Belajar}

Setelah proses pembelajaran berakhir, akan dilakukan pengujian tentang materi yang telah di ajarkan. Data hasil tes sebelum dan setelah mengikuti proses pembelajaran dengan media berupa website joomla yaitu 31 orang mengalami peningkatan, 8 orang diantaranya meningkat cukup signifikan rata-rata diatas $30 \%$ bahkan ada yang meningkat sampai $50 \%, 23$ orang menigkat rata-rata diantara $7 \%-20 \%, 5$ orang tidak mengalami peningkatan, 4 orang mengalam penuruan.

\section{E. Respon Mahasiswa}

Respon siswa terhadap pembelajaran manajemen database dengan media media website ini diperoleh dengan menggunakan angket respon mahasiswa. Angket tersebut diberikan setelah berakhirnya proses pembelajaran. Data yang diperoleh disajikan secara singkat pada tabel 3 berikut ini.

Tabel 3

\section{Hasil Analisis Data Respon Mahasiswa}

\begin{tabular}{|l|c|c|c|c|}
\hline \multirow{2}{*}{ Uraian Pernyataan } & \multicolumn{4}{|c|}{ Respon Mahasiswa } \\
\cline { 2 - 5 } & \multicolumn{2}{|c|}{ Ya } & \multicolumn{2}{c|}{ Tidak } \\
\cline { 2 - 5 } & Jumlah & $\%$ & Jumlah & $\%$ \\
\hline $\begin{array}{l}\text { Apakah pembelajaran dengan media } \\
\text { website ini menarik bagi Anda? }\end{array}$ & 40 & $100 \%$ & 0 & $0 \%$ \\
\hline $\begin{array}{l}\text { Apakah petunjuk dalam merancang } \\
\text { form dalam website ini mudah } \\
\text { dipahami }\end{array}$ & 32 & $80 \%$ & 8 & $20 \%$ \\
\hline
\end{tabular}


Roni Faslah: Pengembangan Pembelajaran Manajemen Database Berbasis Web CMS Joomla Pada Mahasiswa Pendidikan Administrasi Perkantoran FE UNJ

\begin{tabular}{|l|c|c|c|c|}
\hline \multirow{2}{*}{ Uraian Pernyataan } & \multicolumn{4}{|c|}{ Respon Mahasiswa } \\
\cline { 2 - 5 } & \multicolumn{2}{|c|}{ Ya } & \multicolumn{2}{c|}{ Tidak } \\
\cline { 2 - 5 } website ini dapat & Jumlah & $\%$ & Jumlah & $\%$ \\
\hline $\begin{array}{l}\text { Apakah Anda } \\
\text { meningkatkan keterampilan } \\
\text { dalam merancang form }\end{array}$ & 40 & $100 \%$ & 0 & $0 \%$ \\
\hline $\begin{array}{l}\text { Apakah isi dalam websiste seperti ini } \\
\text { sering Anda jumpai dalam kehidupan, } \\
\text { khusus dalam isian formulir }\end{array}$ & 40 & $100 \%$ & 0 & $0 \%$ \\
\hline $\begin{array}{l}\text { Apakah Anda senang jika } \\
\text { pembelajaran manajemen database } \\
\text { ditambah dengan media website? }\end{array}$ & 40 & $100 \%$ & 0 & $0 \%$ \\
\hline
\end{tabular}

Berdasarkan hasil analisis data respon mahasiswa di atas dan kriteria yang telah ditentukan, maka dapat dikatakan bahwa respon mahasiswa terhadap websiste joomla adalah positif, hal ini dapat dilihat dari presentasi totalnya yaitu $96 \%$.

\section{KESIMPULAN}

Berdasarkan hasil analisis data dan pembahasan pada penelitian ini diperoleh kesimpulan sebagai berikut.

1. Tahap pengembangan media website joomla diadaptasi dari model pengembangan Research and Development (R\&D) terdiri dari : (1) potensi dan masalah, (2) pengumpulan data, (3) desain produk, (4) revisi desain, (5) validasi desain dan (6) uji coba produk.

2. Berdasarkan hasil analisis validator maka media website yang dikembangkan ini masuk dalam kategori valid dengan skor kevalidan sebesar 3,45. Kriteria kepraktisan media ini juga dapat dipenuhi karena media media website joomla yang dikembangkan dapat digunakan dengan sedikit revisi.

3. Hasil Belajar mahasiswa menunjukkan bahwa 31 mahasiswasiswa mendapat dampak positif yang ditunjukkan dengan meningkatnya nilai hasil belajar, 5 orang mendapatkan nilai tetap, dan 4 orang mendapatkan nilai yang menurun setelah proses pembelajaran dengan media website joomla ini. Sehingga dapat dikatakan bahwa secara keseluruhan media website joomla ini cukup positif.

4. Respon mahasiswa terhadap pembelajaran dengan media website joomla ini menunjukkan bahwa sebanyak $96 \%$ mahasiswa menunjukan respon positif terhadap pembelajaran dengan media website joomla ini. Maka dapat dinyatakan bahwa respon mahasiswa terhadap pembelajaran dengan menggunakan media website ini 
mendapatkan respon positif dari siswa.

\section{DAFTAR PUSTAKA}

Arikunto, S. 1990. Manajemen Penelitian. Jakarata: Rineka Cipta.

Baisa, Idi Rathomy. 2010. Pengaruh Penerapan Media Pembelajaran Berbasis Web Terhadap Keterampilan Berpikir Kritis Dan Kemampuan Kognitif Siswa Kelas V SD Islam Sabilillah Malang. Tesis tidak diterbitkan. Malang: Universitas Negeri Malang.

Christianti, Meliana dan Djoni Setiawan Kartawihardja. 2005. Media Web Site sebagai Sarana Alternatif dalam MelakukanProses Pembelajaran Secara Elektronik. (Online). (http://repository.maranatha. edu)

Davies, Jo dan Martin Graff. 2005 Performance in e-learning: online participation and student grades. (Online). (http://www.elsinnet.org.uk/r esearch /mgg_files/BJET2005.pdf),

Hendrastomo, Grendi. 2007. Pengembangan E-Learning sebagai Alternatif Model Pembelajaran. (Online). http://staff.uny.ac.id
Jogiyanto. 2002. Sistem Informasi Manajemen. Andi Publisher. Yogyakarta.

Khabibah. 2006 Pengembangan Model Pembelajaran Matematika dengan Soal Terbuka untuk Meningkatkan Kreativitas Siswa Sekolah Dasar. Disertasi Surabaya: Program Pascasarjana Unesa.

Maryani, Sri. 2009. Pengembangan Bahan Ajar Berbasis Multimedia Interaktif Mata Kuliah Komputerisasi Akuntansi (Studi Kasus: Myob Accounting 17 Pada Modul Banking). Online.

Mukhtar dan Iskandar. 2012, Desain Pembelajaran Berbasis TIK, Jakarata: Referensi)

Munir, 2010 Kurikulum Berbasis Teknologi Informasi dan Komunikasi, Bandung : Alfabeta

Oetomo, Budi Sutedjo Dharma, 2002. Perancangan dan Pembangunan Sistem Informasi. Jakarta

Riduwan. 2007. Skala Pengukuran Variabel-Variabel Penelitian. Bandung: Alfabeta.

Rusman dan Deni Kurniawan, Pembelajarn Berbasis Teknologi Informasi

Rusman, 2012. Belajar dan Pembelajaran Berbasis Komputer, Bandung: Alfabeta Rusman, 2011. Model-Model Pembelajaran. Jakarta: Rajawali Pers. 
Sugiyono. 2010. Metode Penelitian Kuantitatif Kualitatif dan R\&D. Bandung: Alfabeta.

Tasri, Lu'mu. 2011. Pengembangan Bahan Ajar Berbasis Web. Jurnal MEDTEK, Volume 3, Nomor 2, Oktober 2011. (Online), http://elektro.unm.ac.id/

Uhefizar, Cara Mudah Membangun Website Interaktif Menggunkan Content Mangement System Jomla
CMS, (Jakarta : PT Gramedia, 2009)

Wahyudi, Mochamad dan Novianti. 2009. Perancangan Website E-learning untuk Kursus Komputer Online menggunakan Moodle. Studi Kasus pada Computer Training Center Bina Sarana Informatika. (Online), (http://id.scribd.com/doc /58491780/Elearning) 